\title{
The Effect of Collaborative Work on Improving Speaking Ability and Decreasing Stress of Iranian EFL Learners
}

\author{
Omid Tabatabaei \\ Department of English, Faculty of Humanities, Najafabad Branch, Islamic Azad University, Najafabad, Isfahan, Iran \\ Mahnaz Afzali \\ Department of English, Faculty of Humanities, Najafabad Branch, Islamic Azad University, Najafabad, Isfahan, Iran \\ Mahmood Mehrabi \\ Department of English, Faculty of Humanities, Najafabad Branch, Islamic Azad University, Najafabad, Isfahan, Iran
}

\section{Doi:10.5901/mjss.2015.v6n4s1p274}

\section{Abstract}

This study aimed to explore the effect of collaborative learning on improving speaking ability and decreasing stress of Iranian EFL learners. To this end, after the administration of the Solution Placement Test (Edwards, 2007), a total of 60 female intermediate EFL learners were selected out of a population pool of 80 studying at a private language institute in Iran. Their age range was between 18 and 22 and they were randomly assigned to two groups of control and experimental $(N=30)$. Participants in experimental group were given some collaborative tasks, they needed to work in groups and those in control group were given the same tasks but they had to do them individually. Each group did the tasks in six sessions. In order to examine the effect of collaborative learning on improving speaking ability, an oral interview was conducted before and after the treatment with all the participants in each group. Furthermore, to examine the effect of collaborative learning on decreasing stress, pre- and post-anxiety tests were administered to the participants. The results of the independent-sample t-test analysis for oral interview revealed that the participants in experimental group outperformed the control group in terms of speaking ability. Also, the results of the independent-sample $t$-test analysis for anxiety posttest revealed that the participants in experimental group had less stress after doing collaborative activities. The attitudes of the participants were explored through a questionnaire which was given to all the participants in the experimental group. The analysis of the responses demonstrated that they had positive attitudes towards collaborative learning. This study offers some implications for EFL teachers, learners, and curriculum designer

Keywords: Anxiety, collaborative learning, fear of negative evaluation, groupwork, speaking ability

\section{Introduction}

Oral communication is an important part of our everyday life and nowadays it is not surprising to hear a person speaks several different languages. However, in most cases we feel most comfortable with speaking our mother tongue since it is the language we have learned naturally. To speak is, therefore, natural for most people and not something we bother to think about. When we speak we also ask for attention, and share our thoughts and feelings with other people. In other words, speaking makes us visible and it is a big part of our social life (Basic, 2011).

As mentioned by Tanveer (2007), an important challenge that most of the L2 learners face in language classes is speaking a second or foreign language. Many learners explain about their inability and sometimes acknowledge their failure in learning to speak an L2. These learners may be good at learning other skills, but when it comes to speaking another language, they often report a mental block (Horwitz, Horwitz\& cope, 1986). In many cases, students' feeling of stress, anxiety or nervousness may hinder their language learning and performance abilities. Second language acquisition (SLA) researchers (Pica, 1986; Birdsong, 1999) have frequently demonstrated that these feelings of anxiety are specially associated with learning and speaking a second/foreign language which distinguishes learning L2 from learning other skills or subjects.

The use of cooperative learning activities provides an alternative instructional practice for teachers by creating more learner- centered classes and focusing on students' learning needs (Nunan, 1992). Teachers using cooperative 
learning activities focus on engaging students in the learning process rather than on the presentation of instruction through direct teaching. During cooperative learning activities teachers have opportunities to observe students' difficulties in learning, also their strengths, and learning styles (Sharan, 1994). Therefore, cooperative learning has benefits for both students and teachers in which teachers can have more concentration on students' needs and students can benefit from their teacher's help.

\section{Review of Litrature}

According to Shabani (2013), speaking in the foreign language has always been considered the most demanding skill compared to other skills such as listening, reading and writing. This is due to the fact that it involves more than knowing the linguistic components of the language. "Of course, knowledge of the linguistic components such as vocabulary and grammatical structures is necessary but not sufficient. What makes speaking different from other skills is that speaker needs to have a quick access to all the relevant knowledge required to produce the appropriate language in the short time, whereas in other skills the learner have enough time to either match the input with the existing knowledge"(Shabani, 2013).

Anxiety has been found to interfere with many types of learning but when it is associated with learning a second or foreign language it is termed as "second/foreign language anxiety". It is a complex and multidimensional phenomenon (Young, 1991) and can be defined as "a subjective feeling of tension, apprehension, nervousness, and worry associated with an arousal of the automatic nervous system" (MCIntyre\& Gardner, 1994, cited in 1999, p.217).Considering L2as a highly influential construct in language learning, researchers have tried to investigate the source that language anxiety can stem from (Tanveer, 2007)."As language anxiety is a psychological construct, it mostly stems from the learner's own "self", i.e., as an intrinsic motivator" (Schwartz, 1972; cited in Scovel 1991,P. 76), e.g. his order perceptions, perceptions about others (peers, teachers, interlocutors, etc) and communication in target language, his/her belief , about L2/FL learning etc. "Language anxiety might be a result of insufficient command of the target language" (Sparks \&Canschow,2000; cited in Horwitz, 2001, p. 118). Language anxiety may be experienced due to linguistic difficulties L2/FL learners have in learning and using the target language. In social context, language anxiety may be experienced because of extrinsic motivators (Schwartz, 1972; cited in Scovel, 1991, P. 16), such as different social and cultural environment, especially environments.

Traditionally, English classes are teacher- centered and probably are not contribute to student's motivation and communication to learn English. Cooperative learning(CL) has become one of the useful devices that uses in language classrooms and promotes student motivation, and student- student interaction (McCafferty, 2006).CL helps teachers in classroom management and provides an alternative instructional practice while creating a more learner- centered atmosphere (Cangelosi, 2000; Sharan, 1994). For students, CL seems to improve their management (Baloche, 1998; Good \&Brophy, 2000), social (Kagan \&Kagan, 1994; Johnson \& Johnson, 1992), and academic skills (Jacob, Rottenberg, Partic\& wheeler, 1969; Stahl, 1995; Wohl\& Klein- Whol, 1994)."Anxiety is a psychological construct, commonly described by psychologists as a state of apprehension, a vague fear that is only indirectly associated with an object" (Hilgard, Atkinson, \& Atkinson, 1971 cited in Scovel, 1991, p.18).

\section{Research Question}

This study has been designed to answer the following research questions:

1. Does the application of collaborative learning lead to better improvement of EFL learners speaking ability?

2. Does the application of collaborative learning lead to the reduction of speaking anxiety among EFL learners?

3. Do Iranian EFL learners have positive attitude towards the application of collaborative learning in EFL conversation classes?

\section{Significance of the Study}

One of the main purposes of learning any language is speaking. As suggested by Tanveer (2007), the issue of language anxiety is being studied with increasing frequency in recent years because of the influence it can have on L2 learning, performance and ultimate achievement. Cooperative learning can be considered as an effective way to reduce the students' anxiety. Also, it may have effects upon students' self-management skills. It may improve students' speaking ability and enable them to establish positive interpersonal relationships.

Thus, the findings of this study can be helpful for both EFL teachers and learners in terms of application of 
collaborative activities in classrooms in order to reduce anxiety in speaking, since foreign language anxiety has negative impact, not only on different aspects of language performance, but also on students' attitudes and perceptions of language learning in general. The investigation of the anxiety- producing factors that arise while learning to communicate in other languages will broaden the insight into the issue of language anxiety. Thus, this study will hopefully help language teachers in making the classroom environment less stressful. Additionally, it is helpful for the teachers to use more collaborative activities in their syllabus.

\section{Methodolog}

\subsection{Participants}

The participants of this study were selected from EFL learners studying at a language Institute in Dorcheh. First, the Solution Placement Test (Edwards, 2007) was administered to 80 female English learners in order to select homogenous participants. Sixty EFL learners were selected as intermediate learners based on their test performance. All the participants were Persian native speakers between 18 and 22 years old and have studied 6 semesters in that institute.

The participants were studying Four Corners 3 and 4 (Richards \&Bohlke, 2012) at the time of the study.Two groups were selected, one as experimental group and one as control group. Each included 30 participants; the experimental group was given collaborative activities while the control group did all the class activities in a noncollaborative way.

\subsection{Instruments}

The instruments used in this study were as follows:

\subsubsection{Solution Placement Test}

The Solution Placement Test (Edwards, 2007) was administered to select a group of homogenous participants. It consists of three sections. The first part of the test includes 50 multiple - choice items of grammar and vocabulary; the second part of the test contains 10 reading comprehension items and the third section is an optional writing task. The 50 multiple - choice questions and the reading task are designed to be done together in a 45- minute session. Since the writing task is optional, it can be done separately and should take approximately 20 minutes. In writing task, the students were asked to write a paragraph about the related topic. Based on the guideline presented by Edwards (2007), learners whose scores fell between 21 and 30 for grammar and vocabulary part of the test and between 5 and 7 for reading were selected as the participants with intermediate level of proficiency.

\subsubsection{Anxiety Pretest}

In order to determine the level of student's anxiety, a pretest was conducted for both groups before the main study. A thirty three -Likert scale- test was adopted for pretest; the items were already designed by Horwitz, Horwitz and cope (1986). The students needed to choose one answer for each question. To determine the content validity of the pretest, some experts were consulted. The test reliability was 0.79 (calculated through Cronbach formula), which was estimated based on a pilot study conducted with 10 EFL Learners.

\subsubsection{Anxiety Posttest}

After the treatment, a posttest was conducted for both groups in order to find out the effectiveness of the treatment on reducing anxiety. The items in the posttest were the same as those of the pretest, just their order changed. For instance, question number 1 changed to question number 5 and so on. The total number of the questions was thirty three, the same as the pretest.

\subsubsection{Questionnaire}

At the end of the treatment, a questionnaire was given to the participants in order to gather information about their attitude towards collaborative learning. To collect the qualitative data of the present study, a questionnaire, including 10 
items, was given to all participants in the experimental group. The items in questionnaire were adapted from different articles. In order to determine the content validity of the questionnaire, some experts were consulted. The test reliability was 0.76 (calculated by Cronbach formula), which was obtained from a pilot study conducted with $10 \mathrm{EFL}$ learners.

These 10 questions elicited students' opinion about collaborative learning and whether it reduces stress.

\subsubsection{Speaking test}

In order to determine the participants' speaking ability, an oral interview was conducted for both groups. The interview items were adopted from Language Assessment (Brown, 2004). To determine the reliability and validity of the oral interview, a pilot study was done before conducting the main study. A group of 10 learners who had the same proficiency level as the main participants of the present study participated in the pilot study. In order to determine the reliability of the oral interview, oral interviews were scored by three experienced English language teachers, then correlation was done for the reported scores, as it was higher than 0.70 , so it was concluded that the interview was reliable. To determine the validity of the contents of the interview, some experienced English language teachers checked the items of interview. All participants in each group participated in interview. The interview for each participant was recorded. After that, three experienced English language teachers listened to the recorded interviews and gave score to each participant. Scoring was based on Language Assessment (Brown, 2004)

\subsection{Procedure}

At first , a Placement Test was administered to a group of female EFL learners $(\mathrm{N}=80)$ at Navayekowsar Institute in Dorche, Isfahan. The 60 female learners whose scores fell between 21 and 30 for grammar and vocabulary part of the test and between 5 and 7 for reading were selected as participants with intermediate level of proficiency. After choosing the appropriate sample, they were randomly assigned to the control and experimental group $(\mathrm{N}=30)$.For each group, a pretest was administered to measure the level of their anxiety. To determine the reliability and validity of the pretest and the posttest, a pilot study was done before conducting the main study. A group of 10 learners who had the same proficiency level as the main participants of the present study participated in the pilot study. The Cronbach formula was used to determine the reliability of the pretest and posttest. As their reliability were higher than 0.75 , it was concluded that the test was reliable. To determine the validity of the contents of the pretest and posttest, some experienced English language teachers checked the content of the pretest and posttest.

Additionally, to determine the participants' speaking ability, an oral interview was done for both groups. All members of each group participated in the interview. The interview was recorded for each participant. Then, three experienced English language teachers listened to the recorded interviews and gave scores for each participant. The students participated in two -hour classes two times a week for six sessions. The same teacher managed these classes in each group in winter 1392. The experimental group members were provided with collaborative tasks during the research. Collaborative activities which were used in this study were adapted from Team-based learning (Michaelsen, Knight\& Fink, 2004). In addition, an oral interview was done for the participants who participated in the first interview to determine the effectiveness of the treatment on their speaking ability. Finally a posttest which was anxiety test the same as the pretest was given to both groups to measure the effectiveness of the treatment.

\subsection{Experimental group}

For experimental group, an introduction was done by the teacher in order to make students familiar with collaborative tasks. Then, the students were asked to sit in groups, each group with three members. Then, a topic was chosen based on brainstorming. In order to help the students in choosing the topic, some topics of Impact Values (Day, Yamanaka\&Shaules,2003) were suggested. A warm- up was done by the teacher in order to encourage students in speaking. Then, the students were asked to discuss the topic for 10 minutes in groups. After that, one member in each group was chosen to summarize their discussion about the topic. It was done for six sessions. However, each session different groups were formed and different students were asked to speak.

\subsection{Control group}

After administering the pretest, the class was conducted for six sessions without any collaborative work. A topic was chosen based on brainstorming. Then, the students were asked to think about the topic for10 minutes. After that, they 
were required to talk about the topic individually. Additionally, all students participated in an oral interview before conducting the study. Finally, after six sessions, they participated in the posttest which was an anxiety test. Also an oral interview was done with all the participants.

\section{Data analysis}

All the data from pretest and posttest, and also interview were fed into the computer and then analyzed using SPSS. The items in the pretest and posttest received 1to 5 score in each question. Also, the score for oral interview was 1 to 5.

To answer the first and second research questions independent sample t-test was applied. In order to answer the third question descriptive statistics (mean, frequency \& standard deviation) and quantitative analysis were used.

\section{Results}

\subsection{The result of oral interview after treatment}

In order to answer the first question of this study -does the application of collaborative learning lead to better improvement of EFL learners' speaking ability- another t-test was applied to the scores of the interview posttest.

Table 1. Descriptive Statistics for interview posttest

\begin{tabular}{cccccc}
\hline & Interview 2 & $\mathrm{N}$ & Mean & Std. Deviation & Std. Error Mean \\
\hline \multirow{2}{*}{ Point } & Experimental Group & 30 & 12.3073 & 2.81490 & .51393 \\
\cline { 2 - 6 } & Control Group & 30 & 10.7743 & 2.82076 & .51500 \\
\hline
\end{tabular}

Table 2. The Results of the Independent-Sample t-test for interview posttest

\begin{tabular}{|c|c|c|c|c|c|c|c|c|}
\hline & \multicolumn{4}{|c|}{$\begin{array}{c}\text { Levene's Test for } \\
\text { Equality of Variances }\end{array}$} & \multicolumn{4}{|c|}{ t-test for Equality of Means } \\
\hline & \multirow[t]{2}{*}{$\mathrm{F}$} & \multirow[t]{2}{*}{ Sig. } & \multirow[t]{2}{*}{$\mathrm{t}$} & \multirow[t]{2}{*}{ df Sig. (2-tailed) } & \multirow{2}{*}{$\begin{array}{c}\text { Mean } \\
\text { Difference }\end{array}$} & \multirow{2}{*}{$\begin{array}{l}\text { Std. Error } \\
\text { Difference }\end{array}$} & \multicolumn{2}{|c|}{$\begin{array}{l}\text { 95\% Confidence Interval } \\
\text { of the Difference }\end{array}$} \\
\hline & & & & & & & Lower & Upper \\
\hline \multirow{2}{*}{$\begin{array}{c}\text { Equal variances } \\
\text { Point } \frac{\text { assumed }}{\text { Equal variances }} \\
\text { not assumed }\end{array}$} & .133 & .716 & 2.10758 & .039 & 1.53300 & .72756 & .07663 & 2.98937 \\
\hline & & & 2.10758 & .039 & 1.53300 & .72756 & .07663 & 2.98937 \\
\hline
\end{tabular}

As it is displayed in Tables 1 and 2 the amount of t-observed for the effect of application of collaborative learning on improvement of EFL learners' speaking ability as $p=0.039$ is less than 0.05 , so the first null hypotheses is rejected (58) $=2.107, p=0.039$ ) and also a statistically significant difference between the two groups is revealed. In other words, the experimental group significantly outperformed the control group. This result rejects the first null hypothesis which states that the application of collaborative learning does not lead to better improvement of EFL learners' speaking ability, and it can be claimed that the application of collaborative learning did affect the improvement of EFL learners' speaking ability.

\subsection{The result of anxiety test after treatment}

In other to analyze the second null hypothesis, an independent sample t-test was run between two groups on the scores of the questionnaire posttest. Tables 3 and 4 show the results of questionnaire posttest.

Table 3. Descriptive Statistics for questionnaire posttest

\begin{tabular}{clcccc}
\hline \multicolumn{5}{c}{ Group Statistics } \\
\hline AnxietyPosttest & $\mathrm{N}$ & Mean & Std. Deviation & Std. Error Mean \\
\hline \multirow{2}{*}{ Point } & Experimental Group & 30 & 56.5667 & 1.19434 & .21805 \\
\cline { 2 - 6 } & Control Group & 30 & 57.7000 & 1.60065 & .29224 \\
\hline
\end{tabular}


Table 4. The Results of the Independent-Sample t-test for questionnaire posttest

\begin{tabular}{|c|c|c|c|c|c|c|c|c|c|c|}
\hline \multicolumn{11}{|c|}{ Independent Samples Test } \\
\hline & & \multicolumn{2}{|c|}{$\begin{array}{l}\text { Levene's Test for } \\
\text { Equality of Variances }\end{array}$} & \multicolumn{7}{|c|}{ t-test for Equality of Means } \\
\hline & & \multirow[t]{2}{*}{$\mathrm{F}$} & \multirow[t]{2}{*}{ Sig. } & \multirow[t]{2}{*}{$\mathrm{t}$} & \multirow[t]{2}{*}{$d f$} & \multirow{2}{*}{$\begin{array}{l}\text { Sig. (2- } \\
\text { tailed) }\end{array}$} & \multirow{2}{*}{$\begin{array}{c}\text { Mean } \\
\text { Difference }\end{array}$} & \multirow{2}{*}{$\begin{array}{l}\text { Std. Error } \\
\text { Difference }\end{array}$} & \multicolumn{2}{|c|}{$\begin{array}{c}95 \% \text { Confidence Interval } 0 \\
\text { the Difference }\end{array}$} \\
\hline & & & & & & & & & Lower & Upper \\
\hline \multirow{2}{*}{ Point } & $\begin{array}{l}\text { Equal variances } \\
\text { assumed }\end{array}$ & 6.097 & .017 & 3.108 & 58 & .003 & -1.13333 & .36462 & -1.86321 & -.40346 \\
\hline & $\begin{array}{l}\text { Equal variances } \\
\text { not assumed }\end{array}$ & & & 3.108 & 3.651 & .003 & -1.13333 & .36462 & -1.86447 & -.40220 \\
\hline
\end{tabular}

According to Table 3, the mean of questionnaire posttest scores for experimental group is 56.56 and for control group is 57.70. As the mean score shows, the learners on experimental group had less stress after doing collaborative tasks in comparison to the control group.

As presented in table 4 the amount of t-observed is -3.108 at the significant level of .003 at the $p<.05$ level ( $t(58)$ $=-3.108, p=0.003$ ) which means that the second null hypothesis is rejected. Therefore, it can be concluded that the experimental group had less stress in comparison to the control group. Therefore, the results show that the application of collaborative learning leads to the reduction of speaking anxiety in EFL learners.

\subsection{Addressing the third research question: The attitude of EFL learners towards collaborative learning}

Table 5. Results of Attitude Questionnaire towards the application of collaborative learning in EFL conversation classes

\begin{tabular}{cccccc}
\hline & Strongly disagree & Disagree & No idea & Agree & Strongly agree \\
\hline 1 & $0 \%$ & $20 \%$ & $0 \%$ & $80 \%$ & $0 \%$ \\
\hline 2 & $0 \%$ & $50 \%$ & $0 \%$ & $0 \%$ & $50 \%$ \\
\hline 3 & $0 \%$ & $20 \%$ & $20 \%$ & $0 \%$ & $60 \%$ \\
\hline 4 & $40 \%$ & $0 \%$ & $10 \%$ & $50 \%$ & $0 \%$ \\
\hline 5 & $0 \%$ & $30 \%$ & $20 \%$ & $50 \%$ & $0 \%$ \\
\hline 6 & $10 \%$ & $30 \%$ & $20 \%$ & $40 \%$ & $0 \%$ \\
\hline 7 & $10 \%$ & $40 \%$ & $10 \%$ & $40 \%$ & $0 \%$ \\
\hline 8 & $70 \%$ & $20 \%$ & $10 \%$ & $0 \%$ & $0 \%$ \\
\hline 9 & $0 \%$ & $10 \%$ & $20 \%$ & $70 \%$ & $0 \%$ \\
\hline 10 & $0 \%$ & $0 \%$ & $70 \%$ & $30 \%$ & $0 \%$ \\
\hline
\end{tabular}

This table shows Iranian EFL learner's attitude towards collaborative learning. This questionnaire was given to all participants in experimental group. $80 \%$ of participants agreed on the importance of collaborative activities for students because of improvement in their speaking ability. Also, 50\% of them thought that collaborative learning leads to improvement of student's speaking. $60 \%$ of learner's believed that collaborative learning helps students to speak with less stress. Also, $50 \%$ of them agreed that collaborative learning is not waste of time. $50 \%$ of students mentioned that collaborative learning leads students to help each other in reducing stress. Furthermore, $40 \%$ of them thought that collaborative learning is more effective for shy students. Also, $40 \%$ of learners agreed that collaborative learning is a good way for improvement of student's speaking. $70 \%$ of them disagreed that being anxious prevents students to speak easily. $70 \%$ of students believed that they feel more stressed when they are exposed to individual tasks. Finally, $30 \%$ of them believed that collaborative learning is just useful for large classes. Altogether, the results showed that they have positive attitude toward collaborative learning.

\section{Conclusion}

The aim of this study was to investigate the effectiveness of collaborative learning on improving speaking ability and decreasing stress of Iranian EFL learners as well as exploring their attitudes towards collaborative learning . The results of this research indicated that learners in experimental group achieved significantly higher scores in both oral interview and posttest than those in control group. These findings were related to the effect of collaborative learning as mentioned 
by Bayat(2004),in intergroup competition, which is provided by $\mathrm{CL}$, anxiety is reduced, interaction among learners is increased and student confidence is enhanced .Also, it is indicated that most of Iranian EFL learners had positive attitude towards collaborative activities.

With regard to using collaborative learning, some cautions should be considered. According to Jacobs (2002), guidelines related to collaborative work should be established early in the semester to reduce student anxiety .Clear instructions to reduce confusion should be made. The students are needed to be helped in order to develop collaborative skills in pairs so they can monitor each other more effectively.

In sum, collaborative learning is a powerful tool in learning and has potential to be used in ways that can make a positive contribution to classroom language learning.

\section{References}

Baloch, L. A. (1988). The cooperative classroom: Empowering learning. Saddle River, NJ: Prentice Hall.

Basic, L. (2011). An obstacle to second language learning? Speaking Anxiety, Hogskolan,Sweden University.

Birdsong, D. (1999). Second language acquisition and the critical period hypothesis. Mahwah, NJ: Lawrence Elbaum Associates.

Brown, H. D. (2004). Language Assessment Principles and Classroom Practices ( $3^{\text {rd }}$ edition). Pearson Education, Inc.

Cangelosi, J.S. (2000). Classroom management strategies (4thed.). New York: John wiley\& Sons, Inc.

Day, R. R., Yamanka, J., \&shaules, J. (2003). Impact values (1sted.). Pearson Education, Inc.

Edwards, L. (2007). Solution Placement Test: Elementary to Intermediate. Oxford University Press.

Good, T. L., \&Brophy, J.E. (2000). Looking in classrooms (8thed.). New York: Longman.

Hilgard, E. R. Atkinson, R. C., \& Atkinson, R. L. (1971). Introduction to psychology (5th edition). New York: Harcourt Brace Jovanovich.

Horwitz, E. K., Horwitz, M. B., \& Cope, J. A. (1986). Foreign Language Classroom Anxiety. The Modern Language Journal, 70(2), 125132.

Jacob, E., Rottenberg, L., Patrick, S., \& wheeler, E. (1969). Cooperative learning: Content and opportunities for academic English. TESOL Quarterly, 30, 253-280.

Jacobs, G.M. Power, M.A., \& Inn, L.W. (2002). The teacher's sourcebook for cooperative learning. Thousand Oaks, CA: Corwin Press, Inc.

Johnson, D. W., \& Johnson, R. T. (1992). Positive interdependence: key to effective cooperation. In R. Hertz- Lazarowitz\& N. Miller (Eds), Interaction in cooperative groups (pp. 174-199). Cambridge: Cambridge University Press

Kagan, S., \& Kagan, M. (1994). The structural approach: six key to cooperative learning. In S. Sharon (Ed.), The handbook f cooperative learning methods (pp. 115-133). Westport, CT: Preager Publishers.

Macintyre, P. D., \& Gardner, R. C. (1994). The subtle effects of language anxiety on cognitive processing in the second language learning. Language learning, 4(4), 283-305.

McCafferty, S. (2006). Cooperative learning and second language teaching. Cambridge University Press, New York, NY.

Michaelsen, L.K., Knight, A.B. \& Fink, L.D. (Eds.) (2004). Team-based learning: A transformative use of small groups in college teaching. Sterling, VA: Stylus.

Nunan, D. (1992). Introduction. In D. Nunan (Ed.), collaborative language learning and teaching (pp.1-10). Cambridge: Cambridge University Press.

Pica, T. (1986). Second Language Acquisition, Social Interaction, and the Classroom. Applied Linguistics, 8(1), 3-21.

Richards, J.C.,\& Rodgers, T.S. (2001). Approaches and Methods in Language Teaching. Cambridge: Cambridge University Press.

Shabani, M.B. (2013). The effect of background knowledge on speaking ability of Iranian EFL learners. International SAMNM Journal of Marketing and Management, 1, 25-27.

Sharan, S. (1994). Cooperative learning and the teacher. In S. Sharan (Ed.)., The handbook of cooperative learning methods, (pp. 336348). Westport, CT: Praeger Publisher.

Sparks, R. J., Ganschow, L., \&Javorsky, J. (2000). Déjà vu all over again. A Response to saito, Horwitz, and Garza. The Modern Language Journal, 84(2), 251-255.

Stahl, R.J. (1995). Cooperative learning: A language arts context and an overview. In R. J. Stahl (Ed.), cooperative learning in language arts (pp. 1-16). Menlo Park, CA: Addison- Wesley Pubishing Company.

Tanveer, M. (2007). Investigation of the factors that cause language anxiety for ESL/ EFL learners in learning speaking skills and the influence it casts communication in the target language. University of Glasgow.

Wohl, A., \& Klein- wohl, E. (1994). Teaching and learning the language arts with cooperative learning methods. In S. Sharan (Ed.), The handbook of cooperative learning methods (pp. 177-192). Westport, CT: Praeger Publishers.

Young, D.J. (1991). Creating a low- Anxiety classroom Environment: what Does Language Anxiety Research Suggest? The Modern Language Journal, 75(4), 426-439. 